\title{
Detection of Resistance Factors in Fish Pathogen Aeromonas liquefaciens
}

\author{
By T. AOKI AND S. EGUSA \\ Department of Fisheries, Faculty of Agriculture, University of Tokyo \\ AND YASUKO OGATA AND T. WATANABE \\ Department of Microbiology, Keio University School of Medicine, \\ Tokyo, Japan
}

(Accepted for publication I5 January I97I)

SUMMARY

Thirty-nine out of 72 drug-resistant strains of Aeromonas liquefaciens isolated from cultured fish and soft-shelled turtles (Trionyx sinensis japonicus) in various districts of Japan carried transferable drug resistance factors. The fish included eel (Anguilla japonica), carp (Cyprinus carpio), ayu (Plecoglossus altivelis) and goldfish (Carassius auratus). The most common type of resistance factors had the markers of resistance to sulphanilamide and tetracycline and all belonged to the $f^{-}$type. Transferable drug resistance was not found in any of 12 strains of $A$. liquefaciens isolated from wild eels. The high incidence of resistance factors in A. liquefaciens from cultured fish is assumed to be due to the selective pressure exerted by chemotherapeutics used in fish culturing.

\section{INTRODUCTION}

The use of antibiotics and other synthetic chemotherapeutics as feed additives for farm livestock, including poultry (see Stokstad, I954; Jukes, 1955) has resulted in an increase in drug-resistant enteric bacteria in these animals, and a majority of these drug-resistant bacteria carry transferable drug resistance factors (or $\mathbf{R}$ factors) (Anderson \& Lewis, 1965; Anderson, 1968, 1969; Smith, 1969). Various antibiotics and synthetic chemotherapeutics have also been used for cultured fish as feed additives in various countries (Schäperclaus, 1955, 1956; Snieszko, 1957, 1959; Hoshina, I962; Wolf \& Snieszko, 1963; Shimizu \& Takase, 1967) to prevent and treat various infections as in other livestock. They have sometimes been administered directly into fish-pond water to control fish infections (Hoshina, I962; Muroga \& Egusa, 1968). There have been several reports which dealt with the drug sensitivities of the fish pathogen Aeromonas liquefaciens (synonyms: A. punctata and A. hydrophila) (Schäperclaus, 1956, 1958; Caselitz \& Maass, 1962; Hoshina, 1962; Karasek, 1967; Shimizu \& Takase, 1967; Muroga \& Egusa, 1968) but other workers have studied rather small numbers of strains.

We had suspected that the use of antibiotics and other chemotherapeutics might have caused an increase in drug-resistant fish-pathogenic bacteria, because of the effects of antibiotic feeding on animal enteric bacteria and also from our knowledge that the administration of drugs to cultured fish has sometimes been ineffective in 
recent years. We have indeed shown that a considerable proportion of Aeromonas liquefaciens strains isolated from cultured fish and soft-shelled turtles (Trionyx sinensis japonicus) are drug-resistant (Aoki \& Egusa, 1971). These fish included eel (Anguilla japonica), carp (Cyprinus carpio), ayu (Plecoglossus altivelis) and goldfish (Carassius auratus). Seventy-eight of 250 strains of $A$. liquefaciens isolated from fish and softshelled turtles were resistant to from one to four drugs excluding aminobenzyl penicillin to which $A$. liquefaciens seems naturally resistant (Aoki \& Egusa, 197I).

We suspected from the patterns of drug resistance of some of the drug-resistant Aeromonas liquefaciens strains that their drug resistances might be due to $\mathrm{R}$ factors. Our preliminary studies with two such strains showed that this was so (Watanabe, Ogata, Aoki \& Egusa, 1969). Their drug resistance markers were found transferable as single units to Escherichia coli $\mathrm{K} \mathrm{I} 2$ in mixed cultivation and they could be spontaneously lost, as units, as shown by the penicillin screening method combined with replica plating (see Watanabe, 1964). We report here a larger scale investigation using the 72 drug-resistant strains of $A$. liquefaciens isolated previously (Aoki \& Egusa, 1971).

\section{METHODS}

Strains. The strains of Aeromonas liquefaciens isolated in our previous study (Aoki \& Egusa, I97I) are listed in Table I and the drug resistance patterns of the drugresistant strains are shown in Table 2. All the strains were isolated from various organs of different individual fish and soft-shelled turtles. Two hundred and forty-four of the 250 strains were isolated from cultured fish or soft-shelled turtles and six strains from diseased wild ayu. We did not include more than one strain isolated from fish from the same fish pond or from fish ponds owned by the same fish culturist. One hundred and fifty-four of the strains studied were from diseased fish or turtles. The other 96 strains were isolated from normal-looking fish.

Table I. Years and sources of the strains of Aeromonas liquefaciens used in the present investigation

\begin{tabular}{|c|c|c|}
\hline Year & Source* & $\begin{array}{l}\text { No. of } \\
\text { strains } \\
\text { isolated }\end{array}$ \\
\hline 1963 & Eel & I \\
\hline I964 & Eel & 4 \\
\hline I965 & Carp & I \\
\hline I966 & Eel & $2 I$ \\
\hline I967 & $\begin{array}{l}\text { Ayu } \\
\text { Eel } \\
\text { Goldfish }\end{array}$ & $\begin{array}{r}12 \\
8 \\
8\end{array}$ \\
\hline 1968 & $\begin{array}{l}\text { Carp } \\
\text { Eel } \\
\text { Goldfish }\end{array}$ & $\begin{array}{r}2 \\
52 \\
3\end{array}$ \\
\hline 1969 & $\begin{array}{l}\text { Carp } \\
\text { Eel } \\
\text { Goldfish } \\
\text { Soft-shelled turtle }\end{array}$ & $\begin{array}{r}24 \\
102 \\
10 \\
2\end{array}$ \\
\hline Total & & 250 \\
\hline
\end{tabular}

* All the sources of Aeromonas liquefaciens strains were cultured fish and soft-shelled turtles except six wild ayu. 
Two hundred and twenty-seven strains $(97.8 \%$ ) of the 232 strains of Aeromonas liquefaciens studied were resistant to more than $200 \mu \mathrm{g}$. of aminobenzyl penicillin $/ \mathrm{ml}$, and 78 out of the 250 total strains isolated were resistant to from one to four other drugs (Aoki \& Egusa, 197I) (Table 2). Six of these drug-resistant strains were lost between the previous study and the present investigation. Besides the above drugresistant strains, I2 A. liquefaciens strains isolated from the intestinal contents of wild eels were also studied for the conjugal transferability of their drug resistances. These strains are not included in Tables I and 2, because their drug resistances were studied with sensitivity discs (Showa) unlike the other strains whose drug resistances were studied by determining the minimal inhibitory concentrations.

Table 2. Drug resistance patterns of resistant strains of Aeromonas liquefaciens isolated from fish and soft-shelled turtles

\begin{tabular}{|c|c|c|c|c|}
\hline Source & $\begin{array}{l}\text { No. of } \\
\text { resistant } \\
\text { strains }\end{array}$ & $\begin{array}{l}\text { No. of } \\
\text { strains } \\
\text { studied }\end{array}$ & $\begin{array}{l}\text { Resistance } \\
\text { pattern* }\end{array}$ & $\begin{array}{l}\text { No. of } \\
\text { strains }\end{array}$ \\
\hline Ayu & 1 & 12 & Tct & I \\
\hline \multirow[t]{6}{*}{ Carp } & 14 & 27 & $\mathrm{Sm}$ & I \\
\hline & & & $\mathrm{Su}$ & 3 \\
\hline & & & & I \\
\hline & & & $\mathrm{Su}, \mathrm{Tc}$ & 4 \\
\hline & & & $\mathrm{Su}, \mathrm{Sm}, \mathrm{Tc}$ & I \\
\hline & & & $\mathrm{Su}, \mathrm{Sm}, \mathrm{Cm}, \mathrm{Tc}$ & 4 \\
\hline \multirow[t]{12}{*}{ Eel } & 59 & 188 & $\operatorname{Sm} \dagger$ & I \\
\hline & & & $\mathrm{Cm}$ & 3 \\
\hline & & & $\mathrm{Tc}$ & 8 \\
\hline & & & Tc $\dagger$ & 3 \\
\hline & & & & 2 \\
\hline & & & $\mathrm{Su}, \mathrm{Tc} \dagger$ & I \\
\hline & & & & 2 \\
\hline & & & $\mathrm{Su}, \mathrm{Tc}$ & 30 \\
\hline & & & $\mathrm{Sm}, \mathrm{Tc}$ & I \\
\hline & & & $\mathrm{Sm}, \mathrm{Nf}$ & I \\
\hline & & & $\mathrm{Su}, \mathrm{Sm}, \mathrm{Tc}$ & 3 \\
\hline & & & $\mathrm{Su}, \mathrm{Sm}, \mathrm{Cm}, \mathrm{Tc}$ & 4 \\
\hline Goldfish & 3 & 21 & Tc & 3 \\
\hline Soft-shelled turtle & $\mathbf{I}$ & 2 & $\mathrm{Su}, \mathrm{Tc}$ & $\mathbf{I}$ \\
\hline Total & 78 & 250 & & 78 \\
\hline
\end{tabular}

* Abbreviations: $\mathrm{Su}$, sulphanilamide; $\mathrm{Sm}$, streptomycin; $\mathrm{Cm}$, chloramphenicol; $\mathrm{Tc}$, tetracycline; $\mathrm{Nf}$, nitrofuran.

$\dagger$ The aminobenzyl penicillin sensitivity of these strains wasnot tested, because they were lost before the test.

$93 \cdot 1 \%$ of the strains listed in this table were resistant to aminobenzyl penicillin.

For methods see text.

Escherichia coli $\mathrm{CSH}-2$ (methionine- and proline-requiring $\mathrm{F}^{-}$derivative of $\mathrm{K}$ I2) was used as a recipient for the conjugal transfer of $\mathrm{R}$ factors from Aeromonas liquefaciens strains. Escherichia coli $\mathrm{w} \mathrm{2252}_{2} / \mathrm{S}^{\mathrm{r}}$ (methionine-requiring, streptomycin-resistant $\mathrm{Hfr}$ derivative of $\mathrm{K} \mathrm{I}$ 2) was used as a host of $\mathrm{R}$ factors for studying the fertility inhibition (fi) property (Watanabe, Fukasawa \& Takano, 1962; Watanabe, Nishida, Ogata, Arai \& Sato, 1964) of the $\mathrm{R}$ factors.

Culture media. Nutrient agar was composed of ro g. beef extract (Kyokuto), Io g. polypeptone (Takeda), 2 g. Bacto agar (Difco) in I l. distilled water. BTB-lactose 
nutrient agar was prepared by adding $0.0045 \%$ bromothymol blue and I $\%$ lactose to nutrient agar, and agar as prescribed by Lennox (1955), all adjusted to $\mathrm{pH} 7 \cdot 3$. The liquid medium used was Bacto Penassay broth (Difco).

Chemotherapeutic agents. Incorporated into BTB-lactose nutrient agar were: sulphathiazole (Su) (Takeda), $500 \mu \mathrm{g} . / \mathrm{ml}$.; chloramphenicol powder (Cm) (Sankyo), $25 \mu \mathrm{g}$./ml.; tetracycline hydrochloride (Tc) (Lederle), $25 \mu \mathrm{g} . / \mathrm{ml}$.; kanamycin sulphate (Km) (Meiji), $50 \mu \mathrm{g} . / \mathrm{ml}$.; dextromycin sulphate $(\mathrm{Nm})$ (Takeda) (identical to neomycin sulphate), $50 \mu \mathrm{g} . / \mathrm{ml}$; aminobenzyl penicillin (Ap) (Meiji), $25 \mu \mathrm{g} . / \mathrm{ml}$; ; or furazolidone (Nf) (Takeda), $12 \cdot 5 \mu \mathrm{g} . / \mathrm{ml}$.

Detection of $R$ factors. Each strain of drug-resistant Aeromonas liquefaciens was incubated in Penassay broth with aeration at $28^{\circ}$ to an extinction equivalent of about $5 \times 10^{8}$ bacteria $/ \mathrm{ml}$. Escherichia coli $\mathrm{CSH}-2$ was incubated in Penassay broth with aeration at $37^{\circ}$ to an equal density. One $\mathrm{ml}$. Aeromonas culture was mixed with I ml. E. coli CSH-2 culture in a test tube and incubated overnight without aeration at either $28^{\circ}$ or $37^{\circ}$ and then plated on BTB-lactose nutrient agar containing each of the drugs to which the Aeromonas strain was resistant. If the drug resistance was transferred to $E$. coli CSH-2, lactose-fermenting colonies would develop among the lactose-nonfermenting growth of Aeromonas colonies. Some strains of $A$. liquefaciens ferment lactose slowly but none formed yellow colonies on the selective media after overnight incubation when plated alone. Each of the colonies of CSH-2 which received drug resistance was re-isolated for purity on a similar selective medium. The purified colony was then tested for resistance to other drugs using sensitivity discs (Showa). In determining drug sensitivities with the discs, $\mathrm{R}^{-}$CSH-2 strain was tested simultaneously as a control.

When the drug resistance of Aeromonas liquefaciens was found transferable to CSH-2, resistance was transferred from $A$. liquefaciens to Escherichia coli $\mathrm{w} 2252 / \mathrm{s}^{\mathrm{r}}$ by mixed cultivation either directly or by way of CSH-2. The procedure used for transferring the drug resistance from $A$. liquefaciens to $\mathrm{w}_{2252} / \mathrm{s}^{\mathrm{r}}$ was the same as that used for

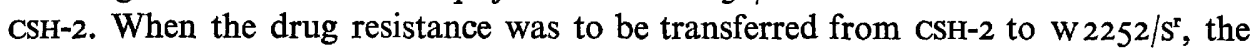
mixed culture of CSH-2 $\left(\mathrm{R}^{+}\right)$and $\mathrm{W} 2252 / \mathrm{s}^{r}$, after incubation overnight, was plated on BTB-lactose nutrient agar containing $1000 \mu \mathrm{g}$. of $\mathrm{Sm} / \mathrm{ml}$. plus each of the other drugs. Since the levels of Sm resistance conferred by $\mathrm{R}$ factors on $E$. coli $\mathrm{K} \mathrm{I} 2$ strains are in the range of 10 to $50 \mu \mathrm{g} . / \mathrm{ml}$. (Watanabe, $1963 b$ ) in contrast to chromosomal $\mathrm{Sm}$ resistance, which is higher than $1000 \mu \mathrm{g} . / \mathrm{ml}$., the donor bacteria do not grow with $1000 \mu \mathrm{g} . / \mathrm{ml}$. of Sm, even if they carry $\mathrm{Sm}$ resistance $\mathrm{R}$ factors. Only the recipient clones which received the $\mathrm{R}$ factors form colonies on such selective media.

Method for study of $f$ property of $R$ factors. $\mathrm{R}$ factors can be classified into $\mathrm{fi}^{+}$and $f$-types depending on the presence and absence of fertility inhibition or the inhibition of the formation of F pili by the sex factor F of Escherichia coli $\mathrm{K}$ I2 (Watanabe et al. 1962; Watanabe, I964; Meynell, Meynell \& Datta, I968). The $\mathrm{fi}^{+}$and $\mathrm{fi}^{-} \mathrm{R}$ factors are probably equal to the F-like and I-like R factors, respectively (Novick, I969). We use our old terms here because we have so far studied only the fertility inhibition property by testing the sensitivity of the $\mathrm{R}$ factor-carrying male bacteria to male-specific bacteriophages (Watanabe et al. 1962) and we have not shown whether they actually produce F pili or I pili.

Each $\mathrm{R}$ factor-carrying $\mathrm{w} 2252 / \mathrm{s}^{\mathrm{r}}$ strain was grown in Penassay broth to about $5 \times 10^{8} / \mathrm{ml}$. and a drop of this culture was added to $2 \mathrm{ml}$. of melted soft Lennox agar 
kept at $48^{\circ}$ and containing $\mathrm{M} / 400 \mathrm{CaCl}_{2}$; this medium was poured on the top of ordinary Lennox agar containing $\mathrm{M} / 400 \mathrm{CaCl}_{2}$. When the soft agar was solidified, a drop of male-specific bacteriophage $\mathrm{f}$ or $\mathrm{f} 2$ (with a titre higher than $\mathrm{I} 0^{9} / \mathrm{ml}$.) was spotted on its surface and the plate incubated at $37^{\circ}$ overnight. If a lytic zone developed, the $\mathbf{R}$ factor was regarded as $f^{-}$, otherwise as $f^{+}$.

\section{RESULTS}

$R$ factors in drug-resistant strains of Aeromonas liquefaciens. Ap resistance was not transferred by any of the Aeromonas liquefaciens studied and so Ap resistance is not included in Table 3. Table 3 shows that two out of 23 one-drug-resistant strains of $A$. liquefaciens transferred their Su resistance to Escherichia coli $\mathrm{CSH}-2$ by mixed cultivation. Thirty-two out of 37 two-drug-resistant strains transferred their $\mathrm{Su}, \mathrm{Tc}$ resistance and one of the two-drug-resistant strains transferred its Tc resistance alone. One out of four $\mathrm{Su}, \mathrm{Sm}, \mathrm{Tc}$-resistant strains could transfer its $\mathrm{Su}, \mathrm{Tc}$ resistance. Two out of eight $\mathrm{Su}, \mathrm{Sm}, \mathrm{Cm}, \mathrm{Tc}-$ resistant strains transferred their $\mathrm{Su}$, Tc resistance, and another strain transferred its $\mathrm{Su}, \mathrm{Cm}, \mathrm{Tc}$ resistance. Transfer of $\mathrm{R}$ factors occurred equally well at $28^{\circ}$ and at $37^{\circ}$.

Table 3. Patterns of drug resistance and their conjugal transferability in Aeromonas

No. of resistance markers

I

2

Total $\quad 72$ liquefaciens isolated from fish and soft-shelled turtles

\begin{tabular}{clccc}
$\begin{array}{c}\text { No. of } \\
\text { strains }\end{array}$ & \multicolumn{1}{c}{$\begin{array}{c}\text { Resistance } \\
\text { pattern* }\end{array}$} & $\begin{array}{c}\text { No. of } \\
\text { strains }\end{array}$ & $\begin{array}{c}\text { No. of } \mathbf{R}^{+} \\
\text {strains }\end{array}$ & $\begin{array}{c}\text { Resistance } \\
\text { pattern of } \\
\text { R factor }\end{array}$ \\
23 & Su & 5 & 2 & Su \\
& Sm & I & o & \\
& Cm & 2 & 0 & \\
& Tc & 13 & 0 & \\
37 & Nf & 2 & 0 & Su, Tc \\
& Su, Tc & 35 & 32 & Tc \\
& Sm, Tc & I & I & \\
4 & Sm, Nf & I & 0 & Su, Tc \\
8 & Su, Sm, Tc & 4 & I & Su, Tc \\
& Su, Sm, Cm, Tc & 8 & 2 & Su, Cm, Tc \\
72 & & & I &
\end{tabular}

* Abbreviations: $\mathrm{Su}$, sulphanilamide; $\mathrm{Sm}$, streptomycin; $\mathrm{Cm}$, chloramphenicol; $\mathrm{Tc}$, tetracycline; $\mathrm{Nf}$, nitrofuran.

$95.8 \%$ of the strains listed in this table were resistant to aminobenzyl penicillin.

All the R factors found in Aeromonas liquefaciens strains were identified as $f i^{-}$type. Transferability of the drug resistance of strains of Aeromonas liquefaciens isolated from wild eels. Three out of 12 strains of Aeromonas liquefaciens isolated from wild eels were resistant to Tc and Ap, three others were resistant to Tc, Nf and Ap, five resistant to $\mathrm{Tc}, \mathrm{Nm}, \mathrm{Nf}$ and $\mathrm{Ap}$, and one was resistant to $\mathrm{Tc}, \mathrm{Km}, \mathrm{Nf}$ and Ap. None transferred their resistance to Escherichia coli by mixed cultivation.

\section{DISCUSSION}

It is characteristic for the $\mathrm{R}$ factors from Aeromonas liquefaciens that a majority of them have Su, Tc resistance markers and that all of them belong to $f^{-}$type, unlike most $\mathrm{R}$ factors from Escherichia coli and Shigella. Even an $\mathrm{R}$ factor with $\mathrm{Cm}$ resistance 
marker detected in a fish was identified as belonging to $f^{-}$type. The $\mathrm{R}$ factors detected in $E$. coli and Shigella in Japan mostly have the markers of resistance to $\mathrm{Su}, \mathrm{Sm}, \mathrm{Cm}$ and Tc and belong to $f^{+}$type (see Watanabe et al. 1962; Watanabe, 1963a,b). R factors can be transferred in vitro to every genus of Enterobacteriaceae as well as to Vibrio and Pasteurella (see Watanabe, 1963a) and also to Aeromonas of human origin (Abe, Goto \& Kuwahara, 1966). Thus it is not surprising that in the present investigation $\mathrm{R}$ factors have been detected in strains of $A$. liquefaciens. It should be emphasized, however, that the $\mathrm{R}$ factors reported here were found in naturally occurring strains of fish pathogen $A$. liquefaciens isolated from fish and soft-shelled turtles.

A majority of the strains of Aeromonas liquefaciens were highly resistant to Ap despite the fact that no penicillin derivative has been used in fish culturing in Japan. None could transfer Ap resistance to Escherichia coli in mixed cultivation. Thus the Ap resistance of $A$. liquefaciens may be regarded as 'natural resistance'. It is interesting to note that the $\mathrm{R}$ factors found in $A$. liquefaciens all belonged to $f^{-}$type and that most of them had the markers of resistance to Su and Tc and neither Sm nor Cm markers. The latter finding is particularly interesting, because $\mathrm{Cm}$ has been used rather extensively for fish culturing in Japan. The cause of this paradoxical finding may be ascribed to the genetic instability of the $\mathrm{Sm}$ and $\mathrm{Cm}$ markers of $\mathrm{R}$ factors in Aeromonas (Abe et al. 1966; and our unpublished data).

The increase of $\mathbf{R}$ factor-carrying enteric bacteria in animal intestines as a result of antibiotic feeding has been a subject of much dispute because of its potential public health hazards; $R$ factors from animals may be dangerous to man either directly, in infections with resistant pathogens such as Salmonella of animal origin (see Anderson, 1968, I969), or indirectly, if R factors are transferred to human pathogens by way of non-pathogenic bacteria such as Escherichia coli (see Watanabe, I963a). The prevalence of $\mathrm{R}$ factor-carrying bacteria among fish pathogen Aeromonas liquefaciens may add another problem to this discussion. Our discovery of $\mathrm{R}$ factor-carrying bacteria in fish seems to have particular importance in Japan because of the importance of fishculturing industry in Japan and also because of the Japanese custom of eating raw fish.

This investigation was supported in part by a Public Health Service research grant AI-08078 from the National Institute of Allergy and Infectious Diseases.

\section{REFERENCES}

ABe, H., Goto, S. \& Kuwahara, S. (I966). Transmission of multiple drug resistance from Shigella to Aeromonas and non-agglutinable Vibrio through conjugation. Japanese Journal of Bacteriology 2I, 266-273.

Anderson, E.S. (1968). The ecology of transferable drug resistance in the Enterobacteria. Annual Review of Microbiology 22, 13 I-1 80.

ANDERSON, E. S. (1969). Ecology and epidemiology of transferable drug resistance. Ciba Foundation Symposium on Bacterial Episomes and Plasmids, pp. I02-1 15. Edited by G. E. W. Wolstenholme \& M. O'Connor. London: J. and A. Churchill.

ANDerson, E. S. \& LewIs, M. J. (1965). Drug resistance and its transfer in Salmonella typhimurium. Nature, London 206, 579-583.

AokI, T. \& EGUSA, S. (1971). Drug sensitivities of Aeromonas liquefaciens isolated from fresh water fishes. Bulletin of the Japanese Society of Scientific Fisheries 37, 19-28.

CASElitz, F. H. \& MAAss, W. (1962). Aeromonasstämme als Krankheitserreger, ihre Empfindlichkeit gegenüber Antibiotika und Sulfonamiden. Deutsche medizinische Wochenschrift. 87, 198-200. 
Hoshina, T. (1962). Studies on red-fin disease of eel. Journal of the Tokyo University of Fisheries 6, I-I05.

JuKes, T. H. (1955). Antibiotics in Nutrition. New York: Medical Encyclopedia Inc.

KARASEK, E. (1967). Untersuchungen zur Aeromonasinfektion kaltblütiger Tiere. Zentralblatt für Veterinärmedizin $\mathbf{4}, 663-670$.

LENNOX, E. S. (1955). Transduction of linked genetic characters of the host by bacteriophage PI. Virology I, 190-206.

Meynell, E., Meynell, G. G. \& Datta, N. (1968). Phylogenetic relationships of drug resistance factors and other transmissible bacterial plasmids. Bacteriological Reviews 32, 55-84.

Muroga, K. \& EGUSA, S. (1968). Chlortetracycline bath as a treatment of bacterial diseases of fish. I. Fish Pathology 2, I4I-I47.

Novick, R. (1969). Extrachromosomal inheritance in bacteria. Bacteriological Reviews 33, 210-235.

SCHÄPERCLAUS, W. (1955). Aufsehenerregende Heilungs- und Bekämpfungserfolge bei der infektiösen Bauchwassersucht des Karpfens durch antibiotische Mittel. Deutsche Fischereizeitung 2, 330-334.

SCHÄPERCLAUS, W. (1956). Bekämpfung der infektiösen Bauchwassersucht des Karpfens durch Antibiotika. Zeitschrift für Fischerei 5, 3-60.

SCHÄPERCLAUS, W. (1958). Bewährung des Chlornitrins in der teichwirtschaftlichen Praxis und neue Versuche über die Anwendbarkeit weiterer Breitspektrum-Antibiotica bei der Bekämpfung der infektiösen Bauchwassersucht des Karpfens. Zeitschrift für Fischerei 7, 599-628.

ShIMIZU, M. \& TAKASE, Y. (1967). A potent chemotherapeutic agent against fish diseases: 6-hydroxymethyl-2-[2-(5-nitro-2-furyl)vinyl] pyridine (P-7138). Bulletin of the Japanese Society of Scientific Fisheries 33, 544-554.

SмrтH, H. W. (1969). Veterinary implications of transfer activity. Ciba Foundation Symposisum on Bacterial Episomes and Plasmids, pp. 213-223. Edited by G. E. W. Wolstenholme \& M. O'Connor. London: J. and A. Churchill.

SNIESZKo, S. F. (1957). Use of antibiotics in the diet of salmonid fishes. Progressive Fish Culturist $\mathbf{1 9}$, $8 \mathrm{I}-84$.

SNIESZKo, S. F. (1959). Antibiotics in fish diseases and fish nutrition. Antibiotics and Chemotherapy 9 , $54 \mathrm{I}-545$.

Stokstad, E. L. R. (1954). Antibiotics in animal nutrition. Physiological Reviews 34, 25-5I.

WatanABE, T. (I963a). Infective heredity of multiple drug resistance in bacteria. Bacteriological Reviews 27, 87-I 15 .

WatanABE, T. (I963b). Episomic resistance factors in Enterobacteriaceae. XX. Levels of drug resistance of Escherichia coli $\mathrm{K} I 2$ with various R factors. Medicine and Biology (Tokyo) 66, I 83-196.

Watanabe, T. (1964). Selected methods of genetic study of episome-mediated drug resistance in bacteria. Methods in Medical Research 10, 202-220.

Watanabe, T., Fukasawa, T. \& TaKano, T. (1962). Conversion of male bacteria of Escherichia coli $\mathrm{K} 12$ to resistance to $f$ phages by infection with the episome 'resistance transfer factor'. Virology I7, 218-219.

Watanabe, T., Nishida, H., Ogata, C., Arat, T. \& Sato, S. (1964). Episome-mediated transfer of drug resistance in Enterobacteriaceae. VII. Two types of naturally occurring R factors. Journal of Bacteriology 88, 716-726.

Watanabe, T., OGata, Y., Aoki, T. \& Egusa, S. (1969). Studies on the drug resistance of fish pathogenic bacteria. I. Detection of R factors. Japanese Journal of Bacteriology 25, 42-43.

Wolf, K. \& SNieszko, S. F. (1963). Uses of antibiotics and other antimicrobials in therapy of diseases of fishes. Antimicrobial Agents and Chemotherapy r, 597-603. 